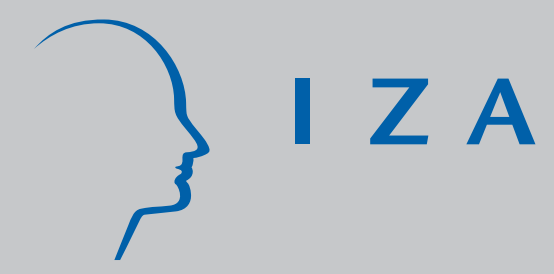

IZADP No. 4143

Return to Training and Establishment Size:

A Reexamination of the Size-Wage Puzzle

Shuaizhang Feng

April 2009 


\title{
Return to Training and Establishment Size: A Reexamination of the Size-Wage Puzzle
}

\author{
Shuaizhang Feng \\ Princeton University \\ and IZA
}

Discussion Paper No. 4143
April 2009

IZA

P.O. Box 7240

53072 Bonn

Germany

Phone: +49-228-3894-0

Fax: +49-228-3894-180

E-mail: iza@iza.org

\begin{abstract}
Any opinions expressed here are those of the author(s) and not those of IZA. Research published in this series may include views on policy, but the institute itself takes no institutional policy positions.

The Institute for the Study of Labor (IZA) in Bonn is a local and virtual international research center and a place of communication between science, politics and business. IZA is an independent nonprofit organization supported by Deutsche Post Foundation. The center is associated with the University of Bonn and offers a stimulating research environment through its international network, workshops and conferences, data service, project support, research visits and doctoral program. IZA engages in (i) original and internationally competitive research in all fields of labor economics, (ii) development of policy concepts, and (iii) dissemination of research results and concepts to the interested public.
\end{abstract}

IZA Discussion Papers often represent preliminary work and are circulated to encourage discussion. Citation of such a paper should account for its provisional character. A revised version may be available directly from the author. 


\section{ABSTRACT}

\section{Return to Training and Establishment Size: A Reexamination of the Size-Wage Puzzle*}

The paper reexamines the employer size-wage puzzle using NLSY79 data. The empirical results show that even for those who never receive any training from their employers, sizewage premium still exists and is quantitatively important. Wage increases associated with receiving on-the-job training are less in large establishments than in small ones. In addition, there is no evidence that starting wages in large establishments are lower than in small establishments. Theories that explain the size-wage puzzle using training and other endogenous productivity differences are not consistent with these new findings.

JEL Classification: J31, J24

Keywords: size-wage premium, return to training, establishment size

Corresponding author:

Shuaizhang Feng

Woodrow Wilson School

Princeton University

Princeton, NJ 08540

USA

E-mail: Shuaizha@Princeton.edu

\footnotetext{
*I thank John Abowd, Francine Blau, Charlie Brown, Peter Gottschalk, Larry Kahn, Alan Krueger, Lars Lefgren and Jesse Rothstein for their comments and suggestions. The paper also benefited from seminar participants at Cornell University, George Washington University and Princeton University. All remaining errors are mine.
} 


\section{Introduction}

Why do larger firms or establishments pay more for (observationally) equivalent workers than smaller firms? While many hypotheses have been explored, this remains one of the most puzzling questions in labor economics. Brown and Medoff (1989) and Troske (1999) carefully examined a comprehensive list of possible explanations, but concluded there still remains a large and significant unexplained employer size-wage premium.

Although worker productivity heterogeneity has always been one of the leading explanations of the puzzle (Brown and Medoff, 1989, Troske, 1999, Gibson and Stillman, 2009), recent theories explicitly point to difference in human capital accumulated on the job between small and large firms or establishments as the possible cause (Troske, 1999, Oi and Idson, 1999, Zabojnik and Bernhardt, 2001). As human capital accumulations are endogenous to firm or establishment size, the fixed effects approach that is usually adopted in the literature is inadequate in controlling for unobserved productivity differences (Gibbons and Katz, 1992). Instead, one needs to directly study these differences, such as training workers received, using suitable data sets.

This paper reexamines the issue of size-wage effect, using a unique data set, the National Longitudinal Study of Youth's 1979 Cohorts (NLSY79). NLSY79 contains very detailed on-thejob training information and has been used extensively in research on return to training (Lynch, 1992, Frazis and Loewenstein, 2005). Thus it is an ideal data set to use for the purpose of controlling for human capital accumulated on the job through training. As a longitudinal data set, NLSY79 also has very low rate of sample attrition, keeps track of complete working histories for workers since labor market entry, and provides measures of pre-market human capital such as 
the Armed Forces Qualification Test (AFQT) score. All of these features allow more precise control of worker heterogeneities than in many previous studies.

The paper focuses on industries that display positive and significant size-wage premium. After further controlling of training status and individual and job level unobserved heterogeneities, I find a large and significant wage differential associated with establishment size even for those who do not receive any training. In addition, workers in large establishments receive a significantly lower return to training than equivalent workers in small establishments: wage return to training in establishments with at least 500 employees is at least $5 \%$ lower than in establishments with less than 500 employees. This finding is quite robust and the differences are always statistically significant.

The presence and significance of size-wage premium for those who never receive training do not support theories attributing the size-wage premium to on-the-job human capital accumulation differences. Observing the fact that large employers and their employees are more likely to invest in firm-specific human capital, Troske (1999) hypothesized that workers in large firms or establishments are paid more because they receive higher levels of firm-specific training (See also Hu, 2003). Similarly, Zabojnik and Bernhardt (2001) developed a model in which corporate tournaments induce workers in large firms to accumulate more general human capital through training. As the two theories rely on differences in training received in large and small firms or establishments, they do not explain why size-wage premium still exists for those who never receive training on the job.

In addition, the finding that return to training is lower in large establishments, is inconsistent with the productivity hypothesis proposed by Oi and Idson (1999). Oi and Idson (1999) conjectured that workers in large firms (establishments) are more productive because the 
production processes are organized differently in large and small firms (establishments). For example, workers in large establishments may have to work harder as production requires team work. However, if similar workers are more productive in large establishments than in small ones, then they should be even more so after receiving training, as training and firm productivity are complements (Bishop, 1997). In a competitive market, return to training should then be larger, not smaller in large establishments.

To summarize, by controlling for training, this paper adds new empirical results to the literature on the employer size-wage effect. These results contradict implications from theories that try to rationalize the existence of size-wage premium in a perfectly competitive setting, by differences in training and other unobserved and possibly size-dependent worker heterogeneities. This suggests that one has to look beyond the competitive paradigm and consider monopsonistic labor market models (Bhaskar, Manning and To 2002, Manning, 2003), of which the on-the-job search model (Burdett and Mortensen, 1998) is the most prominent ${ }^{1}$. Nevertheless, in light of the new empirical findings reported in this paper, these models have to be extended to consider explicitly human capital accumulated on the job.

The rest of the paper is organized as follows. Section 2 of this paper reviews the literature on employer size-wage effect and return to on-the-job training. Section 3 presents empirical results based on NLSY79. Section 4 discusses how these empirical results relate to competing theories of the size-wage premium. The paper concludes in section 5.

\section{Literature Review}

\subsection{Employer-Size Wage Effect}

${ }^{1}$ Green, Machin and Manning (1996) empirically examined the explanatory power of the Burdett-Mortensen search model for the size-wage effect. 
Moore (1911) first found that workers in large Italian textile mills earned more than their counterparts in smaller mills. This turned out to be quite a robust finding across different labor markets. Lester (1967) reported that average hourly earnings in large establishments were 20$25 \%$ above the average hourly earnings in small establishments in the same industry. Using the May 1979 Current Population Survey (CPS) data, Mellow (1982) found that hourly earnings were positively related to both firm and establishment size even after controlling for worker characteristics. Brown, Hamilton and Medoff (1990) also reported similar findings from the May 1983 CPS. Hourly wages in firms with 500 or more employees were 35\% above those in firms with less than 25 workers. The size-wage premium was of similar magnitude to the $36 \%$ male-female wage gap, and exceeded the $29 \%$ union-nonunion and the $14 \%$ white-black wage differences.

Controlling for detailed worker characteristics or looking into narrowly defined occupational subgroups reduces the employer size-wage premium. But the positively inclined size-wage profile remains (Personick and Barsky, 1982, Brown and Medoff, 1989). Even after further control of unobserved worker characteristics, either by the fixed effects approach (Brown and Medoff, 1989), or using Heckman-type selection models (Idson and Feaster, 1990), the wage gains associated with working in a large firm or establishment remain statistically significant and practically large. Using longitudinal data from the Quality of Employment Survey (QES), Brown and Medoff (1989) reported that "if a typical worker went from an establishment with employment one standard deviation below average to an establishment with employment one standard deviation above average, the employee would enjoy a wage increase of 8-12 percent, about as large as the union-nonunion differential in these data.". Using worker-establishment 
matched data, Troske (1999) reported similar findings after controlling for both unobserved worker and establishment effects.

The employer size-wage premium has been one of the most interesting but hard to explain differentials in the labor market. Brown and Medoff (1989) examined six potential explanations, but only found modest support for the worker heterogeneity hypotheses. The five other explanations considered are that large firms offer inferior working conditions; make greater use of high wages to forestall unionization; have stronger ability to pay high wages; face smaller pools of applicants relative to vacancies; or are less able to monitor their workers. In their conclusion, Brown and Medoff (1989) also hypothesized that the employer size-wage relationship may actually be a relationship between firm age and wage since large firms are usually old firms. They later found (Brown and Medoff, 2003) that the firm age-wage relationship is solely explained by observed worker characteristics (see also appendix A of Oi and Idson, 1999 for relevant discussions).

Several recently proposed explanations attribute the observed size-wage premium to productivity differences between workers in large firms (establishments) and small ones that have not been controlled for adequately in previous empirical studies. Troske (1999), in his conclusion section, suggested that both large employers and their employees are more likely to invest in firm-specific human capital. Thus, workers in large firms or establishments are paid more because they receive higher levels of firm-specific training. Similarly, Zabojnik and Bernhardt (2001) developed a model in which corporate tournaments induce workers in large firms to accumulate more general human capital through training. The productivity hypothesis in Oi and Idson (1999) is also similar in spirit - workers in large firms (establishments) are more productive because the production processes are organized differently in large and small firms 
(establishments). As productivity differences associated with size are endogenously determined, fixed effects approach is not adequate in resolving the issue. Rather, it is necessary to control for these differences, such as training workers received, directly, with suitable data sets. This has not been done in previous empirical studies yet, due to data limitations.

\subsection{Return to On-the-job Training}

Training is the most important channel through which workers accumulate human capital while working (Becker, 1964). Economists have been interested in the magnitude of return to training, i.e., the effect of training on workers' wage rates, for both theoretical and policy reasons. Nevertheless, estimating return to training is an empirically difficult task. Unlike full time schooling, training happens after workers enter into the labor market, and is difficult to be measured accurately (See Barron, Berger and Black, 1997 for a discussion of informal training, for example).

Earlier empirical studies on return to training include Mincer (1983, 1988), Brown (1983, 1989), and Lillard and Tan (1992). However, all these studies are based on some proxies, not precise measurement of actual training workers received (Lynch, 1992). Thus, I only review later studies based on NLSY79 ${ }^{2}$. None of the studies, though, have examined whether returns to training differ for workers in different-sized firms or establishments.

Lynch (1992) used the 1979-1986 waves of NLSY79 to study the impact of training (which was categorized as on-the-job training, off-the-job training and apprenticeships) on wages. Basically she specified a cross-sectional model. She also considered the sample selection issue

\footnotetext{
${ }^{2}$ Frazis and Loewenstein (2005) provide the most recent survey of empirical findings on on-thejob training from the NLSY79.
} 
using Heckman's two step estimator, although the adjustment parameter was not statistically significant. She concluded that on-the-job training with the current employer significantly raises wages.

Using later waves of NLSY79, Veum (1995) found that training duration has no effect on wage levels and growth. However, the incidence of on-the-job training was positively related both to 1990 wage levels and to 1986-1990 wage growth.

Frazis and Loewenstein (2005) included all waves of NLSY79 data up to 2000 in their recent study. They used the fixed effects approach and paid special attention to the functional form. They found that the effect of training on wages is very large (several times the return to formal education), even after controlling for differences in wage growth, promotion, and measurement errors. This suggests that there might be substantial heterogeneities in returns to training, and the magnitude of wage increases associated with increases in training hours needs to be interpreted cautiously. Similar to Veum (1995), one does not lose much by including only training incidence (dummy) - even though Frazis and Loewenstein prefer the cubic root function form, using a single training dummy produces almost the same fit and median effect (see: Frazis and Loewenstein, 2005, Table 2, page 458).

\section{Empirical Results}

\subsection{NLSY79 Data}

The empirical analyses in this paper are based on NLSY79 data. The respondents were interviewed annually from 1979 to 1994, and every two years since then. NLSY79 includes a nationally representative cross-sectional sample, a supplemental sample, and a military sample. In this paper, I restrict all analyses to the cross-sectional sample, and focus on the period 19862000, as there were no establishment size (or firm size) information for the period of 1981-1985, 
and some survey questions were restructured after 2000. To get a relatively homogenous group of individuals, I consider only white males that worked full time (defined as 35 hours work per week and above) at nonunion jobs. Self-employed individuals are not included.

NLSY79 provides detailed information about training workers received. Following Frazis and Loewenstein (2005) and other previous studies, this paper focuses on completed on-the-job training spells ${ }^{3}$. In addition, I use a training dummy (training incidence) instead of actual training hours ${ }^{4}$. There are three reasons for doing so. Firstly, training incidence contains much fewer measurement errors than training hours (Barron, Berger and Black, 1997). Secondly, similar to Veum (1995) and Frazis and Loewenstein (2005), the preliminary regressions also suggest that, after controlling for training incidence, hours of training is no longer statistically significant. Lastly, the object of interest here is more about the wage difference between those who receive training and those who do not, and how it varies with establishment size, rather than the incremental wage changes associated with additional training hours.

\footnotetext{
${ }^{3}$ A training spell is defined as on-the-job if it is "company training (type=8)" during the 19791986 surveys, "formal company training run by employer (type=8)" or "training programs at work not run by employer (type=9)" during the 1988-2000 surveys. The 1987 wave of NLSY79 does not contain any training questions. Instead, training happened in the year 1987 were recorded in the 1988 survey.

${ }^{4}$ The 1988-2000 surveys record number of weeks of training and hours of training per week for each training spell. Thus I can calculate total training hours as the product of the two. However, for the period 1979-1986 only weekly training hours are recorded and we need to estimate total training hours. This is done by assuming that number of weeks is 4 per month during the whole training spell following Frazis and Loewenstein (2005).
} 
The paper uses establishment size information, taken from the question "number of employees at location of current job" or "number of employees at location at respondent's job number 1", for all waves except the period of 1981-1985. Firm sizes were not available from the survey $^{5}$, but Brown and Medoff (1989) have shown that the partial effect of establishment size on wage is larger than the firm effect. I follow the literature and use 500 employees as the cutoff point to define establishments as either large or small. Nevertheless, main results from the paper are not changed when alternative cutoff points (250 and 100) or the natural log of establishment size are used ${ }^{6}$.

The analysis uses current job (or CPS job, job number 1) information for the period 19862000. I first transform nominal hourly wages into real wages using CPI-U (1982-1984=100), then exclude values that are greater than $\$ 100$ or less than $\$ 1$. In most years the loss of sample size is less than $2 \%$. For each current job hourly wage, the following information are recorded: year of tenure, total labor market experience, union status on the job, industry, occupation, parttime status, establishment size, local unemployment rate, on-the-job training incidence and hours, and off-the-job training incidence and hours. Variables such as gender, race, education, marriage status, and AFQT score are also included.

\subsection{Preliminary Analyses}

The first empirical task is to use NLSY79 data to reproduce the size-wage effect observed in the previous literature without controlling for training. To start, I run OLS regressions on large establishment size dummy (500+) and other control variables for each industry separately. The

\footnotetext{
${ }^{5}$ For workplaces within the firm, but other than where the employee is working from, NLSY79 only asked for whether the number of employees is over or less than 1,000.

${ }^{6}$ Those results are not included in the paper but are available upon request from the author.
} 
results, as reported in Table A1, show that size-wage effects vary substantially by industry ${ }^{7}$. I then focus on industries that show a positive and significant size-wage premium, including manufacturing, transportation, communication and other public utilities, wholesale and retail trade, business and repair services, and public administration, which together accounts for 63\% of the total sample. Other industries are used as a control later on when conducting the falsification tests.

Sample summary statistics are given in Table 1 . Note that the unit of observation is a person-year. The sample mean of natural log of hourly wage is 6.7 , which corresponds to a real wage rate of $\$ 8$ in 1982-84 dollar. In terms of education, 57\% of the sample has a high school diploma or less, while $19 \%$ of the sample has at least a Bachelor's degree. On average, workers have 4.6 years of tenure with current employers and 11.5 years of total labor market experience. $83 \%$ of the sample work in small establishments, while the rest work in large ones, where large establishments is defined as those with at least 500 employees. Average wage rate for large establishments is substantially higher. Those who work for large establishments earn \$10.6 per hour on average, 38\% higher than those in small establishments. On the other hand, workers in

${ }^{7}$ See also Oi and Idson (1999). Another source of information is provided by U.S. Small Business Administration (SBA) which suggests that average per employee payroll does not always increase with firm or establishment size even when no controls are included (see: http://www.sba.gov/advo/research/data.html). Similarly, Gibson and Stillman (2009) report that size-wage effects differ substantially in different countries using an internationally comparable database. 
large establishments also tend to be more productive, with more years of schooling, higher AFQT scores, longer tenure with current employers and more on-the-job and off-the-job training.

The following ordinary least squares (OLS) model controls for observable characteristics that affect productivities and wages:

$$
L N W_{i t}=\gamma L_{-} E S T_{i t}+x_{i t}^{\prime} \beta+\varepsilon_{i t}
$$

In model (1), ${ }^{i}$ stands for worker and ${ }^{t}$ stands for year. $L N W$ is the log hourly wage, $L_{-} E S T$ is a dummy variable for large establishment, $x$ is the vector of other explanatory variables, including AFQT, schooling dummies, marriage dummies, regional dummies, local unemployment rate, tenure with current job, total labor market experience, and industry dummies.

Model (2) is a panel data model with (unobserved) person effects,

$$
L N W_{i t}=\gamma L_{-} E S T_{i t}+x_{i t}^{\prime} \beta+\phi_{i}+\varepsilon_{i t}
$$

where ${ }^{\phi}$ is the unobserved person effects (indexed only by ${ }^{i}$ ) that do not change for a given worker. The model is estimated using both random effects and fixed effects approaches.

Table 2 reports estimation results. We see that as usual, more schooling is associated with higher earnings. AFQT, tenure and labor market experience are all positively related to hourly wage rate, while workers in areas of high unemployment are paid less. Based on the OLS result, workers in large establishments earn $13.3 \%$ more than those in small ones. When person effects are controlled, the estimated coefficient is reduced to $7.2 \%$ in the random effects specification, and to $5.4 \%$ in the fixed effects specification. Nevertheless, they are all statistically significant at $1 \%$ level. Thus, it is reasonable to conclude that even though a substantial proportion of the sizewage effect is due to worker heterogeneity, the remaining part is still practically important and statistically significant (Brown and Medoff, 1989). 


\subsection{Main Results}

I now consider model (3) which formally introduces on-the-job training into the wage equation and allows for different returns to training in different-sized establishments.

$$
L N W_{i t}=\alpha T R_{i t}+\gamma L_{-} E S T_{i t}+\theta T R L_{i t}+x_{i t}^{\prime} \beta+\varepsilon_{i t}
$$

$T R=1$ if the person has finished at least one on-the-job training spell on the current job by year $t, T R=0$ if not. $T R L$ is the interaction term of $T R$ with $L_{-} E S T$. The parameter of primary interest here is $\theta$, and we are interested in testing whether returns to training differ for different sized establishments.

The first column of Table 3 gives the OLS results. The coefficient on $L_{-} E S T$ is $14 \%$, which is close to that in model (1), but now represents the wage difference between untrained workers in large and small establishments. Return to training is $8.2 \%$ in small establishments, while only $2.9 \%$ in large establishments. The coefficient of TRL equals $-5.1 \%$ and is statistically significant at 5\% level.

One could argue that unobserved worker heterogeneity would bias estimates from the OLS specification. Suppose that the omitted person effect is positively related to whether a person is trained or not $(T R)$, and whether a person is employed in a large establishment $\left(L_{-} E S T\right)$, then the OLS estimates of $\alpha$ and $\gamma$ would be upward biased. However, a priori whether the estimate of $\theta$ is biased, or if biased, the direction of the bias is hard to know. Thus, I consider the following panel model formally:

$$
L N W_{i t}=\alpha T R_{i t}+\gamma L_{-} E S T_{i t}+\theta T R L_{i t}+x_{i t}^{\prime} \beta+\phi_{i}+\varepsilon_{i t}
$$

where $\phi$ is the unobserved person effect. Model (4) is also estimated by both random and fixed effects approaches, with results given in columns two and three in Table 3, respectively. In both 
cases, the coefficients on the large establishment dummy are substantially smaller than that in OLS. Return to training in small establishments is $5.2 \%$ in the random effect specification and $4.6 \%$ in the fixed effects specification, suggesting that workers are selected to training based on unobservable characteristics. Nevertheless, the difference between return to training for small and large establishments $(\theta$ ) becomes even larger, with point estimates at $-6.6 \%$ and $-7.5 \%$ in random and fixed effects specifications, respectively. Both are also statistically significant at the $1 \%$ levels. This indicates that return to training is substantially lower in large establishments even after person effects are taken into account.

The NLSY79 data also contains information regarding the starting and ending date of each job spell, which allows us to explicitly consider job-match effects that do not change during a job spell. The model is as follows.

$$
L N W_{i t}=\alpha T R_{i t}+\gamma L_{-} E S T_{i t}+\theta T R L_{i t}+x_{i t}^{\prime} \beta+\phi_{i}+\eta_{J(i, t)}+\varepsilon_{i t}
$$

In model (5), $\eta$ is the unobserved job-match effect, with $J(i, t)$ indexing the employer for person ${ }^{i}$ at year ${ }^{t}$. The idea is that when a worker and a firm is a good "match", the productivity level would be higher than otherwise. This is in addition to the person specific wage effect captured by $\phi$.

This model can be estimated in three different ways. The first is the usual random effects approach as in model (4). In this case $\phi$ is actually subsumed in $\eta$. The second is the fixed effects approach which uses only within job spell variations. However, results for the job level fixed effects estimation are not reported as within a job, variations in establishment size are 
primarily due to measurement errors. The last one is a two-level mixed model, accounting for both $\phi$ and $\eta$ in the variance-covariance matrix ${ }^{8}$.

Results are reported in the last two columns of Table 3. The random effects results based on job match effects are not greatly different from those based on person effects as in model (4). Again, return to training is smaller in large establishments by $5 \%$ and this difference is statistically significant at $1 \%$ level. For the two-level mixed model, return to training is $3.3 \%$ in small establishments. The coefficient on the interaction term of training and establishment size is $-5.4 \%$ and significant at the $1 \%$ level.

It should also be pointed out that no single specification is clearly preferred to the rest. While the fixed effects estimator is consistent even if person or job-match effects are correlated with the explanatory variables, it uses only within variations and the measurement error problem can be quite severe. Nevertheless, in all specifications there is strong evidence that return to training is lower in large establishments.

Finally, I run wage regressions for those who just started a new job (with at most 1 year job tenure) and have not received any on-the-job training. The results are reported in Table 4. Based on OLS and random effects specifications, those who work in large establishments still earn higher wages than those in small establishments, controlling for everything else. The coefficient for large establishment becomes small and insignificant in the fixed effects specification. Overall,

\footnotetext{
${ }^{8}$ This approach is similar to the random effect specification, as error terms are still assumed to be orthogonal to explanatory variables. However, it allows for two levels (person and job spell) of unobserved effects. The model is estimated using XTMIXED in STATA. For more details, see Searle, Casella and McCulloch (1992).
} 
it is safe to conclude that no evidence suggests those in large establishments earn lower starting wages than their counterparts in small establishments.

\subsection{Robustness Checks}

The empirical work conducted suggests that although size-wage premium exists for untrained workers, it does not seem to hold for trained workers. To put it differently, return to training is smaller in large establishments than in small establishments, with the difference quantitatively important and statistically significant. I consider several robustness checks in this subsection, with results reported in Table A2.

Firstly, I include off-the-job training information in all analyses. Although the focus of this paper is on-the-job training, it makes sense to see whether adding off-the-job training information makes any substantive difference. Essentially all training spells that are not counted as on-the-job training are aggregated to this off-the-job training variable. We also allow tenure effects to be different in large and small establishments, to capture possible differential impacts of informal training that are not recorded in the data. The results are reported in panel A of Table A2. Note that no substantive conclusions about on-the-job training reported previously are changed. The difference between return to on-the-job training in large establishments and small ones remain negative and statistically significant. On the other hand, wage return to off-the-job training is essentially zero once individual heterogeneity is controlled for. The interaction term of off-the-job training is also not significantly different from zero. In addition, note that the coefficients for large establishment remain large (above 7\%) and highly significant in all specifications even though we control for all possibly differential impacts of formal and informal training. 
Secondly, I consider the possible impacts of measurement error in establishment size, which might be particularly problematic for fixed effects specifications. Using UK data, Manning (2003) finds substantial measurement error about establishment size in self-reported employee data. However, as first differencing attenuates the magnitude of all coefficients, the difference in returns to training between small and large establishments would be even larger if there were no measurement errors ${ }^{9}$. In panel B of Table A2, we exclude observations whose establishment size falls between 475 to 525 and run the same set of regressions. In doing so I avoid using size variations that are near the 500 cutoff point which could be mistaken due to misreporting. However, the results are essentially the same as those in Table 3.

Next, the sample is restricted to the period of 1987-2000 and only employer-paid on-thejob training spells are included. Training information is collected differently before and after $1987^{10}$. Also, NLSY79 allows us to identify who paid for on-the-job training in the 1987-2000 surveys. During this period of time, on average, over $90 \%$ of all on-the-job training spells are paid by employers (calculated based on person-year observations), and large establishments paid a higher percentage of on-the-job training spells than smaller ones did. It is plausible that on-the-

\footnotetext{
${ }^{9}$ Barron, Berger and Black (1997) suggest that measurement errors in training variables are unrelated to establishment size.
}

${ }^{10}$ Despite its richness, training information has not been collected consistently in NLSY79 over time. The 1979-1986 surveys records only up to three formal training spells enrolled since last interview and up to two training spells that was still ongoing at last interview. This was followed by a year of absence of training information in 1987. In the 1988-2002 surveys, up to four current and three previous training spells are recorded. Supplemental questions, such as who paid for the training and the usefulness of training programs, were only asked in the latter period. 
job training sessions paid and not paid by employers might have different contents and effects on wages $^{11}$. In fact, Holtmann and Idson (1991) suggest that workers in large firms are paid more because they are more likely to receive employer-paid training, which implies that their starting wages are lower but subsequent wage profiles are steeper. Our results as shown in Panel C of Table A2 suggest that controlling for difference in proportions of employer-paid on-the-job training does not change the main findings.

Lastly, to make sure that our results are not driven by inexperienced workers who might have different levels of attachments to large and small establishments, I restrict the analyses to those with at least 5 years' labor market experience. Once again, results in panel D of Table A2 show no substantive changes from the main results.

To the best of my knowledge, this is the first study that explicitly reports that return to training is smaller in larger establishments. There are findings that are closely related, though. Barron, Black and Loewenstein (1987) found that wage growth is smaller in large firms than in small firms ${ }^{12}$. Brown and Medoff (1989, p.1037) also noted that "A striking regularity among the professional, technical, and managerial workers is the tendency for the wage differential to decline with increasing skill levels".

\subsection{Falsification Tests}

Despite the robustness checks reported above, it is still possible to come up with stories that attribute the lower return to training in large establishments to imperfect control of certain

\footnotetext{
${ }^{11}$ It is also likely that some of the on-the-job training spells are misclassified. Focusing on only employer-paid on-the-job training thus mitigates possible impacts from misclassifications.

${ }^{12}$ Results in this paper suggest that when training is explicitly considered, tenure effects do not differ for small and large establishments.
} 
unobserved factors due to data limitations. For example, if NLSY79 captures less (relatively more formal) training spells in small establishments than in large ones, estimated wage return to training in small establishments could be upward biased.

Therefore, a useful exercise would be to examine what happens in industries that do not show positive size-wage effects which were excluded in earlier analyses. Those industries include agriculture, forestry and fisheries; mining; construction; finance, insurance and real estate; personal services; entertainment and recreation services; education and other professional services. Table A3 presents results for wage regressions without controlling for training, similar to Table 2. The coefficient on large establishment size is almost zero in the OLS specification, but becomes negative and significant in random effects and fixed effects specifications. Based on the fixed effects model, individuals working in large establishments earn $6.2 \%$ lower than their counterparts in small establishments.

Table A4 show the results when on-the-job training information is controlled for. Note that the interaction term of large establishment and training are always positive, although in some specifications not significantly different from zero in a statistical sense. In another word, the results suggest that for those industries that do not exhibit size-wage premium, there is also no evidence that return to training is lower in large establishments. Therefore, positive size-wage premium and lower return to training in large establishments go together. Theories try to explain one have to confront the other as well.

\section{Discussions}

This section examines the validity of several potential explanations of the size-wage premium, given the newly reported empirical findings. Hypotheses considered and rejected in Brown and Medoff (1989) and Troske (1999) will not be considered here further. 
The first explanation to consider is the firm-specific training explanation given by Troske (1999). After examining and refuting a number of popular explanations for the size-wage effect, Troske (1999) offered his own: large firms not only hire more skilled workers, they also "produce" more skilled workers by giving them more specific training. Hu (2003) studied the hiring decisions of large firms and also hypothesized that firm-specific human capital might explain the size-wage effect. She also noted that testing this hypothesis directly is very hard, as data on firm-specific human capital investment and productivity is typically unavailable. The theoretic underpinning of this argument is Becker's original analysis of firm-specific training. In Becker's analysis, workers and firms share the costs and benefits of specific training. If workers in large firms receive more training, then starting wages of these workers would be lower but the subsequent wage growth would be higher. Therefore, for workers who have not received any training, one would observe that those in large establishments to be paid the same as (or even lower than) their counterparts in small establishments. Our empirical results, however, show the opposite to be true.

I then consider the hypothesis of general training proposed by Zabojnik and Bernhardt (2001). They developed a model in which incentives for workers to accumulate general human capital are provided by corporate tournaments. Due to differences in corporate structures and prize sizes, workers in large firms are induced to accumulate more general human capital and are thus paid more. Their argument is similar to the specific training one and it does not imply a size-wage premium for workers who do not receive any training, which is contrary to what this paper found. Their theory also sheds no light on why return to on-the-job training would be lower in large establishments. 
Finally, I consider the productivity hypothesis proposed by Oi and Idson (1999). They claim that workers in large firms or establishments are paid more simply because they are more productive. For example, workers in large firms are required to work in teams, they work harder, use more capital, face a higher customer arrival rate, or have received more training. The central idea is that the production process in large and small firms are organized differently, so that similar workers might have different levels of productivity. This theory is consistent with the observed size-wage premium. It is also different from a simple selection story that could in principal be refuted by controlling for constant person effects using longitudinal data sets, as productivity differences are endogenous. Although one can never control for productivity differences perfectly, productivity hypothesis alone cannot explain why return to training is lower in large establishments. As training and worker productivity are complements, other things equal, one would expect that productivity increases for workers in large firms to be bigger. This has been confirmed empirically by Bishop (1997), who reported that increases in productivity are bigger for workers who receive training in larger establishments ${ }^{13}$. In a competitive setting this would translate into higher wage increases for trained workers in large establishments, not vice versa.

Therefore, the empirical findings in this paper suggest that one cannot easily rationalize the existence of size-wage premium in a competitive setting, using differences in training and other unobserved and possibly size-dependent worker heterogeneities. One has to look beyond the perfect competition paradigm and consider monopsonistic competition models that explicitly

\footnotetext{
${ }^{13}$ The complementarity between training and worker productivity is also demonstrated by the empirical finding that firms usually select better workers to receive on-the-job training (Lynch, 1992, Lillard and Tan, 1992).
} 
incorporate labor market frictions. For example, the analysis in Green, Machin and Manning (1996) about the difference in size-wage premiums in union and non-union jobs actually bears some resemblance to the difference in size-wage premiums for trained and untrained workers. If one assumes that employers always pay less than marginal productivity, then wage distributions of trained workers would be more compressed and the size-wage premium would be accordingly smaller.

Nevertheless, so far, monopsonistic competition models have not provided a direct answer to what would happen to return to training in different sized firms or establishments. For example, Quercioli (2005) extended the Burdett-Mortensen model by allowing firms to provide specific on-the-job training. But in her model, the equilibrium is characterized by all workers in the same firm receiving the same amount of training. Thus it is impossible to compare wages for workers with and without training. Similarly, Fox (2009) uses a hierarchical matching model to interpret the finding that size-wage premiums are higher for white-collar workers with more responsibility. But as he admitted in his paper, the model does not provide an explanation as to why size-wage premium exists even for blue-collar workers.

\section{Conclusions}

This paper presents three novel and robust empirical findings based on NLSY79 data. First, the employer size-wage effect exists even for those who never receive any training. Second, return to training is lower for workers in large establishments than in smaller ones. Last, starting wages in large establishments are not lower than in smaller establishments.

These empirical results dispute certain explanations of the size-wage puzzle, including the productivity hypothesis by Oi and Idson (1999), firm-specific training explanation by Troske (1999), and general training theory by Zabojnik and Bernhardt (2001). All these explanations 
attribute the wage premium associated with employer size to unobserved and endogenous productivity differences, including differences in training workers receive from their employers.

Monopsonistic competition models of labor market that build on labor market frictions, such as the random search model (Burdett and Mortensen, 1998, Green, Machin and Manning, 1996) and the matching models (Shi, 2002, Fox, 2009) may hold more promise toward understanding the puzzle. However, in light of our new empirical findings, these models have to be extended to consider the case of human capital accumulation on the job. Future research should also identify the relative contributions of different kinds of frictions to employer's monopsonistic powers in the actual labor market. 


\section{References}

Barron, John M., Mark C. Berger, and Dan A. Black. 1997. How well do we measure training? Journal of Labor Economics 15(3), 507-528.

Barron, John M., Dan A. Black, and Mark A. Loewenstein. 1987. Employer Size: The Implications for Search, Training, Capital Investment, Starting Wages, and Wage Growth. Journal of Labor Economics 5(1), 76-89.

Becker, Gary S. 1964. Human Capital: A Theoretical and Empirical Analysis, With Special Reference to Education. New York: NBER.

Bhaskar, V., Alan Manning and Ted To. 2002. Oligopsony and monopsonistic competition in labor markets. Journal of Economic Perspectives 16, no. 2 (spring): 155-74.

Bishop, John H. 1997. What we know about employer-provided training: a review of the literature. Research in Labor Economics 16, $19-87$.

Brown, Charles, James Hamilton, James Medoff. 1990. Employers large and small. Cambridge, MA: Harvard University Press.

Brown, Charles, James Medoff. 1989. The employer size wage effect. Journal of Political Economy 97(5), 1027-1059.

Brown, Charles, James Medoff. 2003. Firm age and wages. Journal of Labor Economics 21(3), 677-97.

Brown, James N. 1983. Are Those Paid More Really No More Productive? Measuring the relative performance of tenure as on-the-job training in explaining wage growth. Princeton Industrial Relations Papers.

Brown, James N. 1989. Why do wages increases with tenure? American Economic Review 79, no. 5: 971-91. 
Burdett, Kenneth, Dale T. Mortensen. 1998. Wage differentials, employer size, and unemployment. International Economic Review 39, 257-273.

Fox, Jeremy T. 2009. Firm-size wage gaps, job responsibility, and hierarchical matching. Journal of Labor Economics 27, no. 1: 83-126.

Frazis, Harley, Mark A. Loewenstein. 2005. Reexamining the Returns to Training: Functional Form, Magnitude, and Interpretation. Journal of Human Resources 40, no. 2: 453-76.

Gibbons, Robert, Lawrence Katz. 1992. Does Unmeasured Ability Explain Inter-industry Wage Differentials? Review of Economic Studies 59, no. 3: 515-535.

Gibson, John, Steven Stillman. 2009. Why do big firms pay higher wages? Evidence from an international database. Review of Economics and Statistics 91, no. 1: 213-18.

Green, Francis, Stephen Machin, and Alan Manning. 1996. The employer-size wage effect: Can dynamic monopsony provide an answer? Oxford Economic Papers 48, no. 3 (July): 433-55.

Holtmann, Alphonse G., Todd L. Idson. 1991. Employer Size and On-the-Job Training Decisions. Southern Economic Journal 58, no. 2: 339-55.

Hu, Luojia. 2003. The Hiring Decisions and Compensation Structures of Large Firms. Industrial and Labor Relations Review 56, no. 4: 663-81.

Idson, Todd L., Daniel J. Feaster. 1990. A Selectivity Model of Employer-Size Wage Differentials. Journal of Labor Economics 8, no. 1: 99-122.

Lester, Richard. 1967. Pay differentials by size of establishment. Industrial Relations 7, no. 1: 57-67.

Lillard, Lee A., Hong W. Tan. 1992. Private Sector Training: Who Gets it and What Are its Effects. Research in Labor Economics 13: 1-62. 
Lynch, Lisa M. 1992. Private-Sector Training and the Earnings of Young Workers. American Economic Review 82, no. 1: 299-312.

Manning, Alan. 2003. Monopsony in motion: Imperfect competition in labor markets. Princeton, NJ: Princeton University Press.

Mellow, W. 1982. Employer size and wages. Review of Economics and Statistics 64, 495-501.

Mincer, Jacob. 1983. Union Effects: Wages, Turnover and Job Training. Research in Labor Economics 5: 217-52.

Mincer, Jacob. 1988. Job Training, Wage Growth and Labor Turnover. NBER working paper No. 2090.

Moore, Henry L. 1911. Laws of wages. (Macmillan, New York) reprinted 1967, Augustus M. Kelley, New York.

Oi, Walter Y., Todd L. Idson. 1999. Firm size and wages. Handbook of labor economics, vol. 3, edited by Orley Ashenfelter and David Card, 2165-2215.

Personick, Martin E., Carl B. Barsky. 1982. White-collar pay levels linked to corporate work force size. Monthly Labor Review 105: 23-28.

Quercioli, Elena. 2005. Training, Turnover, and Search. International Economic Review 46: 13343.

Searle, Shayle R., George Casella, and Charles E. McCulloch. 1992. Variance Components. New York, NY: John Wiley and Sons.

Shi, Shouyong. 2002. Product market and the size-wage differential. International Economic Review 43, no. 1: 21-54.

Troske, Kenneth R. 1999. Evidence on the employer size-wage premium from worker establishment matched data. Review of Economics and Statistics 81, no. 1: 15-26. 
Veum, Jonathan R. 1995. Sources of training and their impact on wages. Industrial and Labor Relations Review 48, no. 4: 812-26.

Zabojnik, Ján, Dan Bernhardt. 2001. Corporate Tournaments, Human Capital Acquisition, and the Firm size-wage relation. Review of Economic Studies 68, no. 3: 693-716. 
Table 1: Sample Means and Standard Deviations.

\begin{tabular}{lccc}
\hline & Whole Sample & $\begin{array}{c}\text { Large Establishments } \\
(500+)\end{array}$ & Small Establishments \\
& & & \\
\hline Log wage & $6.70(0.51)$ & $6.97(0.47)$ & $6.65(0.51)$ \\
Education & & & \\
- Less than 12 years & 0.11 & 0.07 & 0.11 \\
- 12 years & 0.46 & 0.36 & 0.48 \\
- 13-15 years & 0.24 & 0.22 & 0.25 \\
- 16 years & 0.16 & 0.28 & 0.14 \\
- more than 16 years & 0.03 & 0.07 & 0.02 \\
AFQT & $56.01(27.31)$ & $64.24(27.99)$ & $54.3(26.86)$ \\
Local Unemployment Rate & $2.64(0.90)$ & $2.49(0.79)$ & $2.67(0.91)$ \\
Job Tenure & $4.62(4.67)$ & $5.62(4.91)$ & $11.46(4.67)$ \\
Labor Market Experience & $11.54(4.72)$ & $11.95(4.91)$ & 0.16 \\
On-the-job Training & & & $22.81(164.42)$ \\
- Incidence (dummy) & 0.2 & 0.36 & \\
- duration (hours) & $29.79(179.01)$ & $63.8(234.72)$ & 0.13 \\
Off-the-job Training & 0.14 & & $18.71(130.93)$ \\
- Incidence (dummy) & $21.88(150.80)$ & $37.22(222.74)$ & - \\
- duration (hours) & 0.17 & - & \\
Establishment size $>=500$ & & & \\
\hline
\end{tabular}

Note: Total number of observations is 9,314. Standard deviations are given in parentheses when the variable is not a dummy. 
Table 2: Wage Regressions Not Controlling for Training

\begin{tabular}{llll}
\hline & OLS & $\begin{array}{l}\text { Random } \\
\text { Effects, Person } \\
\text { level }\end{array}$ & $\begin{array}{l}\text { Fixed Effects, } \\
\text { Person Level }\end{array}$ \\
\hline Large Establishments $(500+)$ & $0.133^{* * *}$ & $0.072^{* * *}$ & $0.054^{* * *}$ \\
Education & $(0.010)$ & $(0.010)$ & $(0.013)$ \\
- Less than 12 years & $-0.072^{* * *}$ & $-0.063^{* *}$ & NA \\
- 13-15 years & $(0.014)$ & $(0.028)$ & \\
& $0.141^{* * *}$ & $0.134^{* * *}$ & NA \\
- 16 years & $(0.012)$ & $(0.023)$ & \\
- more than 16 years & $0.272 * * *$ & $0.303^{* * *}$ & NA \\
AFQT & $(0.015)$ & $(0.030)$ & \\
Local Unemployment Rate & $0.345^{* * *}$ & $0.400^{* * *}$ & NA \\
Job Tenure & $(0.029)$ & $(0.050)$ & \\
Job Tenure Squared & $0.002^{* * *}$ & $0.002^{* * *}$ & NA \\
Labor Market Experience & $(0.0002)$ & $(0.0004)$ & \\
& $-0.030^{* * *}$ & $-0.029^{* * *}$ & $-0.028^{* * *}$ \\
& $(0.005)$ & $(0.005)$ & $(0.005)$ \\
& $0.036^{* * *}$ & $0.034^{* * *}$ & $0.032^{* * *}$ \\
& $(0.003)$ & $(0.003)$ & $(0.003)$ \\
& $-0.001^{* * *}$ & $-0.002^{* * *}$ & $-0.002^{* * *}$ \\
& $(0.0002)$ & $(0.0002)$ & $(0.0002)$ \\
& $0.033^{* * *}$ & $0.041^{* * *}$ & $0.044^{* * *}$ \\
& $(0.004)$ & $(0.004)$ & $(0.006)$ \\
& $-0.0004^{* *}$ & $-0.0006^{* * *}$ & $-0.0007^{* * *}$ \\
& $(0.0002)$ & $(0.0002)$ & $(0.0002)$ \\
\hline
\end{tabular}

Note: Dependent variable is log wage. Number of observations is 9,314. The other explanatory variables are regional dummies, marriage dummies, and industry dummies. The base group workers are full-time white males with 12 years of schooling, work in a small-sized establishment. Robust standard errors are reported in parentheses. ${ }^{* * *}$ stands for significance at $1 \%$ level, ${ }^{* *}$ stands for significance at $5 \%$ level, ${ }^{*}$ stands for significance at $10 \%$ level. 
Table 3: Wage Regressions Controlling for Training.

\begin{tabular}{|c|c|c|c|c|c|}
\hline & OLS & $\begin{array}{l}\text { Random } \\
\text { Effects, } \\
\text { Person Level }\end{array}$ & $\begin{array}{l}\text { Fixed Effects, } \\
\text { Person Level }\end{array}$ & $\begin{array}{l}\text { Random } \\
\text { Effects, Job } \\
\text { Level }\end{array}$ & $\begin{array}{l}\text { Mixed Effects, } \\
\text { Person and } \\
\text { Job Levels }\end{array}$ \\
\hline \multirow[t]{2}{*}{ Large Establishments $(500+)$} & $0.140 * * *$ & $0.087 * * *$ & $0.072 * * *$ & $0.072 * * *$ & $0.058 * * *$ \\
\hline & $(0.012)$ & $(0.012)$ & $(0.015)$ & $(0.012)$ & $(0.013)$ \\
\hline \multirow[t]{2}{*}{ On-the-job Training } & $0.082 * * *$ & $0.052 * * *$ & $0.046^{* * *}$ & $0.032 * * *$ & $0.033^{* * *}$ \\
\hline & $(0.012)$ & $(0.011)$ & $(0.014)$ & $(0.012)$ & $(0.013)$ \\
\hline \multirow[t]{2}{*}{$\begin{array}{l}\text { Large Establishments (500+) } \\
\text { x On-the-job training }\end{array}$} & $-0.051 * *$ & $-0.066 * * *$ & $-0.075^{* * *}$ & $-0.050^{* * *}$ & $-0.054 * * *$ \\
\hline & $(0.020)$ & $(0.019)$ & $(0.022)$ & $(0.019)$ & $(0.020)$ \\
\hline \multicolumn{6}{|l|}{ Education } \\
\hline \multirow[t]{2}{*}{ - Less than 12 years } & $-0.068 * * *$ & $-0.062 * *$ & NA & $-0.053 * * *$ & $-0.059 * *$ \\
\hline & $(0.014)$ & $(0.028)$ & & $(0.019)$ & $(0.028)$ \\
\hline \multirow[t]{2}{*}{ - 13-15 years } & $0.137 * * *$ & $0.133 * * *$ & NA & $0.142 * * *$ & $0.131^{* * *}$ \\
\hline & $(0.012)$ & $(0.023)$ & & $(0.017)$ & $(0.021)$ \\
\hline \multirow[t]{2}{*}{ - 16 years } & $0.270 * * *$ & $0.302 * * *$ & NA & $0.327 * * *$ & $0.316^{* * *}$ \\
\hline & $(0.015)$ & $(0.030)$ & & $(0.023)$ & $(0.028)$ \\
\hline \multirow[t]{2}{*}{ - more than 16 years } & $0.342 * * *$ & $0.400 * * *$ & NA & $0.432 * * *$ & $0.423^{* * *}$ \\
\hline & $(0.029)$ & $(0.050)$ & & $(0.043)$ & $(0.052)$ \\
\hline \multirow[t]{2}{*}{ AFQT } & $0.002^{* * *}$ & $0.002 * * *$ & NA & $0.002 * * *$ & $0.003^{* * *}$ \\
\hline & $(0.0002)$ & $(0.0004)$ & & $(0.0003)$ & $(0.0004)$ \\
\hline \multirow[t]{2}{*}{ Local Unemployment Rate } & $-0.031 * * *$ & $-0.029 * * *$ & $-0.028 * * *$ & $-0.025^{* * *}$ & $-0.024 * * *$ \\
\hline & $(0.005)$ & $(0.005)$ & $(0.005)$ & $(0.004)$ & $(0.005)$ \\
\hline \multirow[t]{2}{*}{ Job Tenure } & $0.033^{* * *}$ & $0.033 * * *$ & $0.031 * * *$ & $0.033^{* * *}$ & $0.031 * * *$ \\
\hline & $(0.003)$ & $(0.003)$ & $(0.003)$ & $(0.003)$ & $(0.002)$ \\
\hline \multirow[t]{2}{*}{ Job Tenure Squared } & $-0.001 * * *$ & $-0.002 * * *$ & $-0.002 * * *$ & $-0.002 * * *$ & $-0.001 * * *$ \\
\hline & $(0.0002)$ & $(0.0002)$ & $(0.0002)$ & $(0.0002)$ & $(0.0001)$ \\
\hline \multirow[t]{2}{*}{ Labor Market Experience } & $0.032 * * *$ & $0.040 * * *$ & $0.044 * * *$ & $0.032 * * *$ & $0.036^{* * *}$ \\
\hline & $(0.004)$ & $(0.004)$ & $(0.006)$ & $(0.004)$ & $(0.004)$ \\
\hline \multirow[t]{2}{*}{$\begin{array}{l}\text { Labor Market Experience } \\
\text { Squared }\end{array}$} & $-0.0004 * *$ & $-0.0006^{* * *}$ & $-0.0006^{* * *}$ & $-0.0003 *$ & $-0.0004 * * *$ \\
\hline & $(0.0002)$ & $(0.0002)$ & $(0.0002)$ & $(0.0002)$ & $(0.0001)$ \\
\hline
\end{tabular}

Note: Dependent variable is log wage. Number of observations is 9,314. The other explanatory variables are regional dummies, marriage dummies, and industry dummies. The base group workers are full-time white males with 12 years of schooling, work in a small-sized establishment. Robust standard errors are reported in parentheses. ${ }^{* * *}$ stands for significance at $1 \%$ level, ${ }^{* *}$ stands for significance at $5 \%$ level, $*$ stands for significance at $10 \%$ level. 
Table 4: Wage Regressions for Starting Wages

\begin{tabular}{|c|c|c|c|}
\hline & OLS & $\begin{array}{l}\text { Random } \\
\text { Effects, } \\
\text { Person Level }\end{array}$ & $\begin{array}{l}\text { Fixed Effects, } \\
\text { Person Level }\end{array}$ \\
\hline Large Establishments (500+) & $\begin{array}{l}0.059 * * \\
(0.024)\end{array}$ & $\begin{array}{l}0.054 * * \\
(0.023)\end{array}$ & $\begin{array}{l}0.016 \\
(0.033)\end{array}$ \\
\hline \multicolumn{4}{|l|}{ Education } \\
\hline - Less than 12 years & $\begin{array}{l}-0.026 \\
(0.024)\end{array}$ & $\begin{array}{l}-0.043 \\
(0.030)\end{array}$ & NA \\
\hline - 13-15 years & $\begin{array}{l}0.083^{* * *} \\
(0.024)\end{array}$ & $\begin{array}{l}0.093^{* * *} \\
(0.030)\end{array}$ & NA \\
\hline - 16 years & $\begin{array}{l}0.283^{* * *} \\
(0.037)\end{array}$ & $\begin{array}{l}0.294 * * * \\
(0.043)\end{array}$ & NA \\
\hline - more than 16 years & $\begin{array}{l}0.428 * * * \\
(0.076)\end{array}$ & $\begin{array}{l}0.457 * * * \\
(0.080)\end{array}$ & NA \\
\hline AFQT & $\begin{array}{l}0.001^{* * *} \\
(0.0004)\end{array}$ & $\begin{array}{l}0.001^{* * *} \\
(0.0005)\end{array}$ & NA \\
\hline Local Unemployment Rate & $\begin{array}{l}-0.046^{* * *} \\
(0.009)\end{array}$ & $\begin{array}{l}-0.042^{* * *} \\
(0.009)\end{array}$ & $\begin{array}{l}-0.038 * * * \\
(0.013)\end{array}$ \\
\hline Job Tenure & $\begin{array}{l}0.264^{* *} \\
(0.120)\end{array}$ & $\begin{array}{l}0.216^{*} \\
(0.113)\end{array}$ & $\begin{array}{l}0.052 \\
(0.144)\end{array}$ \\
\hline Job Tenure Squared & $\begin{array}{l}-0.151 \\
(0.115)\end{array}$ & $\begin{array}{l}-0.110 \\
(0.109)\end{array}$ & $\begin{array}{l}0.068 \\
(0.141)\end{array}$ \\
\hline Labor Market Experience & $\begin{array}{l}0.037 * * * \\
(0.007)\end{array}$ & $\begin{array}{l}0.039 * * * \\
(0.008)\end{array}$ & $\begin{array}{l}0.048^{* * *} \\
(0.013)\end{array}$ \\
\hline Labor Market Experience Squared & $\begin{array}{l}-0.0005 \\
(0.0003)\end{array}$ & $\begin{array}{l}-0.0005 \\
(0.0003)\end{array}$ & $\begin{array}{l}-0.0006 \\
(0.0005)\end{array}$ \\
\hline
\end{tabular}

Note: Dependent variable is log wage. Number of observations is 2,287. The other explanatory variables are regional dummies, marriage dummies, and industry dummies. The base group workers are full-time white males with 12 years of schooling, work in a small-sized establishment, and with less than or equal to one year job tenure with current employer. Robust standard errors are reported in parentheses. $* * *$ stands for significance at $1 \%$ level, ${ }^{* *}$ stands for significance at $5 \%$ level, * stands for significance at $10 \%$ level. 
Table A1: OLS regressions of log wage on large establishment by industry

\begin{tabular}{|c|c|c|c|c|}
\hline & $\begin{array}{l}\text { OLS } \\
\text { Estimates }\end{array}$ & $\begin{array}{l}\text { Robust } \\
\text { Standard } \\
\text { Errors }\end{array}$ & R-squared & $\begin{array}{l}\text { Number of } \\
\text { observations }\end{array}$ \\
\hline $\begin{array}{l}\text { Agriculture, Forestry, and } \\
\text { Fisheries }\end{array}$ & -0.110 & $(0.127)$ & 0.31 & 559 \\
\hline Mining & 0.110 & $(0.147)$ & 0.49 & 164 \\
\hline Construction & 0.540 & $(0.038)$ & 0.24 & 1938 \\
\hline Manufacturing & $0.144^{* * *}$ & $(0.013)$ & 0.50 & 3564 \\
\hline $\begin{array}{l}\text { Transportation, Communication, } \\
\text { and Other Public Utilities }\end{array}$ & $0.107 * * *$ & $(0.031)$ & 0.36 & 1087 \\
\hline Wholesale Trade & $0.258 * * *$ & $(0.054)$ & 0.42 & 605 \\
\hline Retail Trade & $0.082 * *$ & $(0.034)$ & 0.31 & 2059 \\
\hline $\begin{array}{l}\text { Finance, Insurance and Real } \\
\text { Estate }\end{array}$ & 0.019 & $(0.037)$ & 0.50 & 855 \\
\hline Business and Repair Services & $0.124 * * *$ & $(0.039)$ & 0.44 & 1385 \\
\hline Personal services & 0.868 & $(0.113)$ & 0.37 & 246 \\
\hline $\begin{array}{l}\text { Entertainment and Recreation } \\
\text { Services }\end{array}$ & -0.020 & $(0.093)$ & 0.38 & 249 \\
\hline Health Services & $-0.188 * * *$ & $(0.049)$ & 0.45 & 447 \\
\hline Education Services & 0.070 & $(0.052)$ & 0.32 & 424 \\
\hline Other Professional Services & 0.015 & $(0.051)$ & 0.27 & 610 \\
\hline Public Administration & $0.128 * * *$ & $(0.029)$ & 0.46 & 614 \\
\hline
\end{tabular}

Note: Dependent variable is log of wage. Other control variables are also included. Robust standard errors are reported in parentheses. *** stands for significance at $1 \%$ level, ** stands for significance at $5 \%$ level, * stands for significance at $10 \%$ level. 


\begin{tabular}{|c|c|c|c|c|c|}
\hline & OLS & $\begin{array}{l}\text { Random } \\
\text { Effects, } \\
\text { Person } \\
\text { Level }\end{array}$ & $\begin{array}{l}\text { Fixed } \\
\text { Effects, } \\
\text { Person } \\
\text { Level }\end{array}$ & $\begin{array}{l}\text { Random } \\
\text { Effects, } \\
\text { Job Level }\end{array}$ & $\begin{array}{l}\text { Mixed } \\
\text { Effects, } \\
\text { Person and } \\
\text { Job Levels }\end{array}$ \\
\hline \multicolumn{6}{|c|}{ A: Adding Off-the-job Training and Allow Tenure Effects to be different } \\
\hline Large Establishment & $\begin{array}{l}0.123^{* * *} \\
(0.019)\end{array}$ & $\begin{array}{l}0.084^{* * *} \\
(0.017)\end{array}$ & $\begin{array}{l}0.076^{* * *} \\
(0.020)\end{array}$ & $\begin{array}{l}0.083 * * * \\
(0.018)\end{array}$ & $\begin{array}{l}0.074 * * * \\
(0.018)\end{array}$ \\
\hline On-the-job Training & $\begin{array}{l}0.074 * * * \\
(0.012)\end{array}$ & $\begin{array}{l}0.052^{* * *} \\
(0.011)\end{array}$ & $\begin{array}{l}0.047^{* * *} \\
(0.014)\end{array}$ & $\begin{array}{l}0.031^{* *} \\
(0,012)\end{array}$ & $\begin{array}{l}0.033 * * * \\
(0.013)\end{array}$ \\
\hline Large Establishment x On-the-job training & $\begin{array}{l}-0.050^{* *} \\
(0.021)\end{array}$ & $\begin{array}{l}-0.069 * * * \\
(0.019)\end{array}$ & $\begin{array}{l}-0.073 * * * \\
(0.023)\end{array}$ & $\begin{array}{l}-0.047 * * \\
(0.019)\end{array}$ & $\begin{array}{l}-0.054^{* *} \\
(0.022)\end{array}$ \\
\hline Off-the-job Training & $\begin{array}{l}0.069 * * * \\
(0.014)\end{array}$ & $\begin{array}{l}0.003 \\
(0.015)\end{array}$ & $\begin{array}{l}-0.015 \\
(0.019)\end{array}$ & $\begin{array}{l}0.003 \\
(0.015)\end{array}$ & $\begin{array}{l}-0.005 \\
(0.014)\end{array}$ \\
\hline Large Establishment $x$ Off-the-job training & $\begin{array}{l}-0.082^{* * *} \\
(0.025)\end{array}$ & $\begin{array}{l}0.006 \\
(0.024)\end{array}$ & $\begin{array}{l}0.029 \\
(0.029) \\
\end{array}$ & $\begin{array}{l}0.025 \\
(0.023) \\
\end{array}$ & $\begin{array}{l}0.028 \\
(0.026) \\
\end{array}$ \\
\hline \multicolumn{6}{|c|}{ B: Excluding Those with Establishment Size between 475 and 525} \\
\hline Large Establishment & $\begin{array}{l}0.134^{* * *} \\
(0.013)\end{array}$ & $\begin{array}{l}0.082^{* * *} \\
(0.013)\end{array}$ & $\begin{array}{l}0.067^{* * *} \\
(0.017)\end{array}$ & $\begin{array}{l}0.072 * * * \\
(0.013)\end{array}$ & $\begin{array}{l}0.067 * * * \\
(0.014)\end{array}$ \\
\hline On-the-job Training & $\begin{array}{l}0.082 * * * \\
(0.012)\end{array}$ & $\begin{array}{l}0.052^{* * *} \\
(0.011)\end{array}$ & $\begin{array}{l}0.046^{* * *} \\
(0.014)\end{array}$ & $\begin{array}{l}0.031 * * * \\
(0.012)\end{array}$ & $\begin{array}{l}0.033 * * * \\
(0.013)\end{array}$ \\
\hline Large Establishment x On-the-job training & $\begin{array}{l}-0.045^{* *} \\
(0.022)\end{array}$ & $\begin{array}{l}-0.061 * * * \\
(0.020)\end{array}$ & $\begin{array}{l}-0.072 * * * \\
(0.024)\end{array}$ & $\begin{array}{l}-0.048^{* *} \\
(0.021)\end{array}$ & $\begin{array}{l}-0.051^{* *} \\
(0.022)\end{array}$ \\
\hline \multicolumn{6}{|c|}{ C: Restricting to Post-1987 years and employer-paid on-the-job Training } \\
\hline Large Establishment & $\begin{array}{l}0.142^{* * *} \\
(0.012)\end{array}$ & $\begin{array}{l}0.089 * * * \\
(0.012)\end{array}$ & $\begin{array}{l}0.075^{* * *} \\
(0.015)\end{array}$ & $\begin{array}{l}0.072 * * * \\
(0.012)\end{array}$ & $\begin{array}{l}0.070^{* * *} \\
(0.013)\end{array}$ \\
\hline On-the-job Training & $\begin{array}{l}0.079 * * * \\
(0.012)\end{array}$ & $\begin{array}{l}0.047 * * * \\
(0.011)\end{array}$ & $\begin{array}{l}0.039 * * * \\
(0.014)\end{array}$ & $\begin{array}{l}0.035^{* * *} \\
(0.012)\end{array}$ & $\begin{array}{l}0.034^{* * * *} \\
(0.013)\end{array}$ \\
\hline Large Establishment x On-the-job training & $\begin{array}{l}-0.054^{* * *} \\
(0.020)\end{array}$ & $\begin{array}{l}-0.073^{* * *} \\
(0.019)\end{array}$ & $\begin{array}{l}-0.083^{* * *} \\
(0.021)\end{array}$ & $\begin{array}{l}-0.052^{* * *} \\
(0.019)\end{array}$ & $\begin{array}{l}-0.058^{* * *} \\
(0.021)\end{array}$ \\
\hline \multicolumn{6}{|c|}{ D: Restricting to those with at least 5 years' labor market experience } \\
\hline Large Establishment & $\begin{array}{l}0.146^{* * *} \\
(0.012)\end{array}$ & $\begin{array}{l}0.090 * * * \\
(0.012)\end{array}$ & $\begin{array}{l}0.074 * * * \\
(0.015)\end{array}$ & $\begin{array}{l}0.072 * * * \\
(0.012)\end{array}$ & $\begin{array}{l}0.071 * * * \\
(0.014)\end{array}$ \\
\hline On-the-job Training & $\begin{array}{l}0.081 * * * \\
(0.012)\end{array}$ & $\begin{array}{l}0.046^{* * * *} \\
(0.011)\end{array}$ & $\begin{array}{l}0.039 * * * \\
(0.014)\end{array}$ & $\begin{array}{l}0.031^{* *} \\
(0.012)\end{array}$ & $\begin{array}{l}0.029 * * \\
(0.013)\end{array}$ \\
\hline Large Establishment x On-the-job training & $\begin{array}{l}-0.054^{* * *} \\
(0.020)\end{array}$ & $\begin{array}{l}-0.072^{* * *} \\
(0.019)\end{array}$ & $\begin{array}{l}-0.082 * * * \\
(0.022)\end{array}$ & $\begin{array}{l}-0.052 * * * \\
(0.020)\end{array}$ & $\begin{array}{l}-0.058^{* * *} \\
(0.021)\end{array}$ \\
\hline
\end{tabular}

Note: Same specifications as in Table 3. Robust standard errors are reported in parentheses. ${ }^{* * *}$ stands for significance at $1 \%$ level, ${ }^{* *}$ stands for significance at $5 \%$ level, * stands for significance at $10 \%$ level. 
Table A3: Wage Regressions Not Controlling for Training, for Industries with NO size-wage premium

\begin{tabular}{llll}
\hline & OLS & $\begin{array}{l}\text { Random Effects, } \\
\text { Person Level }\end{array}$ & $\begin{array}{l}\text { Fixed Effects, } \\
\text { Person Level }\end{array}$ \\
\hline Large Establishments $(500+)$ & 0.007 & $-0.038^{* *}$ & $-0.062^{* *}$ \\
Education & $(0.018)$ & $(0.019)$ & $(0.025)$ \\
- Less than 12 years & & & \\
& $-0.037^{*}$ & -0.034 & NA \\
- 13-15 years & $(0.021)$ & $(0.035)$ & \\
& $0.173^{* * *}$ & $0.188^{* * *}$ & NA \\
- 16 years & $(0.019)$ & $(0.032)$ & \\
& $0.259 * * *$ & $0.310^{* * *}$ & NA \\
- more than 16 years & $(0.023)$ & $(0.039)$ & \\
AFQT & $0.393^{* * *}$ & $0.435^{* * *}$ & NA \\
Local Unemployment Rate & $(0.033)$ & $(0.061)$ & \\
Job Tenure & $0.002^{* * *}$ & $0.002^{* * *}$ & NA \\
Job Tenure Squared & $(0.0003)$ & $(0.0005)$ & \\
Labor Market Experience & $-0.021^{* * *}$ & $-0.016^{* *}$ & -0.014 \\
& $(0.007)$ & $(0.007)$ & $(0.010)$ \\
& $0.031^{* * *}$ & $0.026^{* * *}$ & $0.022^{* * *}$ \\
& $(0.004)$ & $(0.004)$ & $(0.005)$ \\
& $-0.001^{* * *}$ & $-0.001^{* * *}$ & $-0.001^{* * *}$ \\
& $(0.0003)$ & $(0.0002)$ & $(0.0003)$ \\
& $0.025^{* * *}$ & $0.040^{* * *}$ & $0.048^{* * *}$ \\
& $(0.006)$ & $(0.006)$ & $(0.009)$ \\
& -0.00003 & $-0.0005^{* *}$ & $-0.0007^{* *}$ \\
& $(0.0002)$ & $(0.0002)$ & $(0.0003)$ \\
\hline
\end{tabular}

Note: Dependent variable is log wage. Number of observations is 5,546. The other explanatory variables are regional dummies, marriage dummies, and industry dummies. The base group workers are full-time white males with 12 years of schooling, work in a small-sized establishment. Robust standard errors are reported in parentheses. ${ }^{* * *}$ stands for significance at $1 \%$ level, ${ }^{* *}$ stands for significance at $5 \%$ level, ${ }^{*}$ stands for significance at $10 \%$ level. 
Table A4: Wage Regressions Controlling for Training, for Industries with NO size-wage premium

\begin{tabular}{|c|c|c|c|c|c|}
\hline & OLS & $\begin{array}{l}\text { Random } \\
\text { Effects, } \\
\text { Person } \\
\text { Level }\end{array}$ & $\begin{array}{l}\text { Fixed } \\
\text { Effects, } \\
\text { Person } \\
\text { Level }\end{array}$ & $\begin{array}{l}\text { Random } \\
\text { Effects, Job } \\
\text { Level }\end{array}$ & $\begin{array}{l}\text { Mixed } \\
\text { Effects, } \\
\text { Person and } \\
\text { Job Levels }\end{array}$ \\
\hline \multirow[t]{2}{*}{ Large Establishment } & -0.016 & $-0.045^{* *}$ & $-0.063 * *$ & -0.033 & $-0.042^{* *}$ \\
\hline & $(0.021)$ & $(0.021)$ & $(0.028)$ & $(0.020)$ & $(0.020)$ \\
\hline \multirow[t]{2}{*}{ On-the-job Training } & 0.016 & 0.020 & 0.017 & 0.011 & 0.011 \\
\hline & $(0.021)$ & $(0.021)$ & $(0.029)$ & $(0.020)$ & $(0.023)$ \\
\hline \multirow{2}{*}{$\begin{array}{l}\text { Large Establishment x On-the-job } \\
\text { training }\end{array}$} & $0.087^{* *}$ & 0.029 & 0.002 & $0.077^{* *}$ & 0.061 \\
\hline & $(0.039)$ & $(0.034)$ & $(0.040)$ & $(0.031)$ & $(0.038)$ \\
\hline \multicolumn{6}{|l|}{ Education } \\
\hline - Less than 12 years & $\begin{array}{l}-0.037^{*} \\
(0.021)\end{array}$ & $\begin{array}{l}-0.034 \\
(0.035)\end{array}$ & NA & $\begin{array}{l}-0.049 * \\
(0.027)\end{array}$ & $\begin{array}{l}-0.041 \\
(0.036)\end{array}$ \\
\hline - 13-15 years & $\begin{array}{l}0.172 * * * \\
(0.019)\end{array}$ & $\begin{array}{l}0.187^{* * * *} \\
(0.032)\end{array}$ & NA & $\begin{array}{l}0.187^{* * *} \\
(0.026)\end{array}$ & $\begin{array}{l}0.185 * * * \\
(0.031)\end{array}$ \\
\hline - 16 years & $\begin{array}{l}0.261 * * * \\
(0.023)\end{array}$ & $\begin{array}{l}0.306^{* * *} \\
(0.039)\end{array}$ & NA & $\begin{array}{l}0.288 * * * \\
(0.033)\end{array}$ & $\begin{array}{l}0.304 * * * \\
(0.040)\end{array}$ \\
\hline - more than 16 years & $\begin{array}{l}0.391 * * * \\
(0.033)\end{array}$ & $\begin{array}{l}0.434 * * * \\
(0.061)\end{array}$ & NA & $\begin{array}{l}0.458 * * * \\
(0.048)\end{array}$ & $\begin{array}{l}0.443 * * * \\
(0.054)\end{array}$ \\
\hline AFQT & $\begin{array}{l}0.002 * * * \\
(0.0003)\end{array}$ & $\begin{array}{l}0.002^{* * *} \\
(0.0005)\end{array}$ & NA & $\begin{array}{l}0.002 * * * \\
(0.0004)\end{array}$ & $\begin{array}{l}0.002 * * * \\
(0.0005)\end{array}$ \\
\hline Local Unemployment Rate & $\begin{array}{l}-0.020 * * * \\
(0.007)\end{array}$ & $\begin{array}{l}-0.016^{* *} \\
(0.007)\end{array}$ & $\begin{array}{l}-0.014 \\
(0.010)\end{array}$ & $\begin{array}{l}-0.022^{* * *} \\
(0.007)\end{array}$ & $\begin{array}{l}-0.019 * * * \\
(0.007)\end{array}$ \\
\hline Job Tenure & $\begin{array}{l}0.029 * * * \\
(0.004)\end{array}$ & $\begin{array}{l}0.025 * * * \\
(0.004)\end{array}$ & $\begin{array}{l}0.021 * * * \\
(0.005)\end{array}$ & $\begin{array}{l}0.027 * * * \\
(0.004)\end{array}$ & $\begin{array}{c}0.025 * * * \\
(0.004)\end{array}$ \\
\hline Job Tenure Squared & $\begin{array}{l}-0.001^{* * *} \\
(0.0003)\end{array}$ & $\begin{array}{l}-0.001^{* * *} \\
(0.0002)\end{array}$ & $\begin{array}{l}-0.001^{* * *} \\
(0.0003)\end{array}$ & $\begin{array}{l}-0.001^{* * *} \\
(0.0002)\end{array}$ & $\begin{array}{l}-0.001^{* * *} \\
(0.0002)\end{array}$ \\
\hline Labor Market Experience & $\begin{array}{l}0.024 * * * \\
(0.006)\end{array}$ & $\begin{array}{l}0.040^{* * *} \\
(0.006)\end{array}$ & $\begin{array}{l}0.048^{* * *} \\
(0.009)\end{array}$ & $\begin{array}{l}0.027 * * * \\
(0.006)\end{array}$ & $\begin{array}{l}0.034 * * * \\
(0.006)\end{array}$ \\
\hline Labor Market Experience Squared & $\begin{array}{l}-0.00002 \\
(0.0003)\end{array}$ & $\begin{array}{l}-0.0005^{* *} \\
(0.0002)\end{array}$ & $\begin{array}{l}-0.0007 * * \\
(0.0003)\end{array}$ & $\begin{array}{l}-0.0001 \\
(0.0002)\end{array}$ & $\begin{array}{l}-0.0003 \\
(0.0002)\end{array}$ \\
\hline
\end{tabular}

Note: Dependent variable is log wage. Number of observations is 5,546. The other explanatory variables are regional dummies, marriage dummies, and industry dummies. The base group workers are full-time white males with 12 years of schooling, work in a small-sized establishment. Robust standard errors are reported in parentheses. ${ }^{* * *}$ stands for significance at $1 \%$ level, ${ }^{* *}$ stands for significance at $5 \%$ level, $*$ stands for significance at $10 \%$ level. 